\title{
Stormont House Agreement: Model Implementation Bill
}

\author{
Kieran McEvoy, AnNa Bryson, Brian Gormally, Daniel \\ GreenberG, Jeremy Hill, Daniel Holder, Louise Mallinder and \\ GEMMA MCKEOWN*
}

\section{ARRANGEMENT OF CLAUSES}

PART 1

\section{PRELIMINARY}

Stormont House Agreement founding principles

1 Founding principles

$$
\text { Key concepts }
$$

2 "Troubles-related"

3 "Perpetrator"

4 "Investigating bodies"

PART 2

\section{HISTORICAL INVESTIGATIONS UNIT}

Nature and status

5 Establishment

6 Family support staff

7 Independence

8 Finance

9 Five-year target

\section{Functions}

10 Duty to carry out investigations

11 Cases falling within HIU's jurisdiction

* The authors would like to acknowledge the financial assistance of the Arts and Humanities Research Council (Grant Reference AH/J013897/1) and the Queen's University Belfast Business Alliance. The authors' affiliations are as follows: Kieran McEvoy and Anna Bryson, Queen's University Belfast; Brian Gormally, Daniel Holder and Gemma McKeown, Committee on the Administration of Justice; Daniel Greenberg, barrister specialising in legislation and the legislative process; Jeremy Hill and Louise Mallinder, Ulster University. 
Conduct of investigations

12 Priorities

13 Policing powers

Reports of investigations' conclusions

14 Report to DPPNI

15 Report to deceased's family

16 Report to other victims' families

17 Interim reports

18 Public statements

19 Non-publication of information putting lives at risk

Relationship with other bodies

20 Other investigations

21 International obligations

22 Disclosure to HIU

23 Transfer of legacy files

24 Failure to cooperate

25 Referrals from the DPPNI

26 Disclosure to the ICIR

27 Duties to co-operate with the Coroner

28 Oversight by the Policing Board

29 Inspection of the HIU

30 HIU complaints

31 Finance of external bodies supporting HIU functions

PART 3

\section{INDEPENDENT COMMISSION ON INFORMATION RETRIEVAL}

32 Establishment

33 Capacity, immunities and finance

34 "Victims and survivors"

35 The work of the ICIR

\section{PART 4 \\ IMPLEMENTATION AND RECONCILIATION GROUP}

Definitions

36 Definitions

$$
\text { Nature, status and organisation }
$$

37 Establishment

38 Chair of the IRG

39 Other members of the IRG

40 Remuneration and allowances 
41 Secretariat

42 Funding

43 Annual report

44 Governance

45 Duration

Objective and functions

46 Objective and functions

47 Exercise of functions

Relationship with other bodies

48 Relationship with other bodies

Report on themes

49 Report on themes

50 Evidence base

\section{PART 5}

\section{ORAL HISTORY ARCHIVE}

Definitions

51 Definitions

Establishment and operation

52 Establishment

53 Principles of operation

54 Code of Practice

Nature and Status

55 Capacity

56 Immunity from suit

Governance

57 Appointment of Executive Board and Advisory Board

58 Tenure of Executive Directors

59 Tenure of members of Advisory Board

60 Secretariat

Finance

61 Remuneration and allowances

62 Funding

Work of the $\mathrm{OHA}$

63 Work of the OHA

64 Arrangements with PRONI

65 Engagement with contributors

Handling of information

66 Obtaining and holding information

67 Publication of information 
Arrangements with the Republic of Ireland

68 Arrangements with the Republic of Ireland

PART 6

\section{GENERAL}

69 Interpretation

70 Regulations and orders

\section{SCHEDULES}

SCHEDULE 1

STAFF AND PROCEEDINGS OF THE DIRECTOR OF THE HISTORICAL INVESTIGATIONS UNIT

SCHEDULE 2

TEXT OF THE AGREEMENT BETWEEN THE UNITED KINGDOM AND IRELAND ON THE ESTABLISHMENT OF THE INDEPENDENT COMMISSION ON INFORMATION RETRIEVAL 


\section{PART 1}

\section{PRELIMINARY}

Stormont House Agreement founding principles

\section{Founding principles}

(1) This section sets out principles which are to be considered-

(a) by public authorities in exercising functions under this Act, and

(b) by courts and tribunals in interpreting and applying this Act.

(2) These principles are referred to in this Act as "the founding principles" and may be referred to in other legislation, instruments and documents as "the Stormont House Agreement Founding Principles".

(3) The founding principles are-

(a) That the cause of reconciliation should be promoted.

(b) That the rule of law should be upheld.

(c) That the suffering of victims and survivors should be acknowledged and addressed.

(d) That it is right to facilitate the pursuit of justice and the recovery of information.

(e) That fundamental rights (including the Convention Rights within the meaning of section 1 of the Human Rights Act 1998 and other international standards) must be protected.

(f) That the approach to addressing issues arising from the past of Northern Ireland should be balanced, proportionate, transparent, fair and equitable.

$$
\text { Key concepts }
$$

\section{2 “Troubles-related"}

(1) A "troubles-related death" is a death which occurred in or after 1966 as a result of or in connection with political conflict in Northern Ireland.

(2) A "qualifying human rights breach" is a breach of Article 2 or 3 of the Convention (within the meaning of the Human Rights Act 1998) which occurred as a result of or in connection with political conflict in Northern Ireland.

(3) For the purposes of this section-

(a) it is immaterial whether a result or connection was direct or indirect; and

(b) it is immaterial how long a person took to die.

\section{3 "Perpetrator"}

(1) A person is a perpetrator in respect of an offence which resulted in a troubles-related death or in respect of a qualifying human rights breach if the person-

(a) committed the offence or breach (whether or not jointly with another and whether or not through another person),

(b) ordered, solicited or induced the commission of the offence or breach

(c) knowingly facilitated the commission of the offence or breach, or

(d) in any other way knowingly contributed to the commission of the offence or breach by a group of persons acting with a common purpose.

(2) In this section-

(a) a reference to an offence includes a reference to an attempted offence (in which case the reference to an offence which resulted in a troubles-related death includes a reference to an offence which was intended or likely to result in a troubles-related death); 
(b) a reference to facilitating an offence or breach includes a reference to aiding or abetting it, or otherwise doing anything designed to encourage the commission of the offence or breach,

(3) In the application of this section to Part 2 a reference to an offence includes a reference to an act which amounted to professional misconduct (or to an attempted act which would have amounted to professional misconduct).

\section{4 “Investigating bodies"}

The following are investigating bodies for the purposes of this Act-

(a) the Police Service of Northern Ireland (including the Historical Enquiries Team);

(b) the Police Ombudsman for Northern Ireland;

(c) the Royal Military Police;

(d) the Royal Ulster Constabulary;

(e) the Police Complaints Board for Northern Ireland; and

(f) the Independent Commission for Police Complaints for Northern Ireland.

\section{PART 2}

\section{HISTORICAL INVESTIGATIONS UNIT}

Nature and status

\section{Establishment}

(1) There is to be an independent Historical Investigations Unit ("the HIU") to carry out investigations into troubles-related deaths and qualifying human rights breaches.

(2) The First Minister and Deputy First Minister must appoint a person as Director of the HIU.

(3) Before making an appointment the First Minister and Deputy First Minister must consult the Department of Justice.

(4) The First Minister and Deputy First Minister must-

(a) aim to appoint a person who will be seen as credible by persons with an interest in the exercise of functions under this Part, and

(b) publish a statement of their reasons for thinking that the person appointed satisfies paragraph (a).

(5) The Director of the HIU is a corporation sole.

(6) In making arrangements for staff the Director must aim, so far as is practicable, to secure a gender-balance and the necessary experience and aptitude to provide a gender-sensitive approach to the exercise of the HIU's functions.

(7) The Policing Board shall issue, and may from time to time revise, a Code of Ethics for the purpose of-

(a) laying down standards of conduct and practice for HIU staff;

(b) making HIU staff aware of the rights and obligations arising out of fundamental rights (including the Convention Rights within the meaning of section 1 of the Human Rights Act 1998 and other international standards).

(8) Schedule 1 makes additional provision about the staff, proceedings and the Code of Ethics for the HIU.

\section{HIU family support staff}

(1) The HIU shall make arrangements for the appointment of dedicated family support staff to- 
(a) involve the victims' family from the beginning of an investigation, and

(b) provide them with advice and other necessary support throughout the process.

(2) Arrangements under subsection (1) are without prejudice to any other rights of family members to involvement in investigations

\section{Independence}

(1) The HIU must be administered in a way that ensures that persons carrying out or involved in an investigation have no connection with persons whose behaviour is being investigated or might require to be investigated.

(2) In subsection (1) "connection" includes-

(a) present and past connections; and

(b) both actual connections and connections that might reasonably be perceived or suspected.

(3) The reference in subsection (1) to involvement in an investigation includes a reference to the provision of research, archiving and other supporting functions.

(4) The HIU may not employ (in any capacity) a person who-

(a) has at any time been a member of the Royal Ulster Constabulary;

(b) is or has at any time been a member of the security service within the meaning of the Security Service Act 1989;

(c) is or has at any time been a member of any of the armed forces of the United Kingdom (including a voluntary or reserve force);

(d) has been convicted (at any time) of an offence relating to membership of a proscribed organisation contrary to section 11 of the Terrorism Act 2000 or a provision of any of the Northern Ireland (Emergency Provisions) Acts.

(5) Subsection (4) is without prejudice to the generality of subsection (1).

(6) In reflecting the founding principle relating to the protection of fundamental rights the HIU must have regard to any documents dealing with international human rights standards or practice that the HIU considers relevant.

\section{Finance}

(1) The Treasury must determine-

(a) amounts to be paid to or in respect of the Director of the HIU (by way of or in respect of remuneration, allowances and pension), and

(b) maximum amounts of expenditure by the Director of the HIU in respect of staff and administration.

(2) Amounts paid under subsection (1)(a) and amounts of expenditure incurred under subsection (1)(b) are to be charged on, and paid out of, the Consolidated Fund.

\section{Five-year target}

(1) The HIU must plan to complete the functions assigned to it by this Part by the end of the period of five years beginning with the date on which this section comes into force.

(2) The Secretary of State may by regulations amend subsection (1) so as to increase the length of the specified period.

(3) The Secretary of State must make provision for an increase under subsection (2) if-

(a) the Secretary of State is satisfied that the increase is necessary in order to ensure compliance with international obligations of the United Kingdom in respect of human rights, or 
(b) the increase is requested by the First Minister and Deputy First Minister on the grounds that there is work under this Part which the HIU has not yet completed and which it should be enabled to complete.

\section{Functions}

\section{Duty to carry out investigations}

(1) The function of the HIU is to investigate-

(a) deaths which appear to the HIU to be troubles-related, and

(b) alleged or suspected human rights breaches which appear to the HIU to be qualifying human rights breaches.

(2) In subsection (1)(b)-

(a) "alleged" means alleged in a complaint made to the Police Ombudsman for Northern Ireland or to the HIU, and

(b) "suspected" means suspected by the HIU on reasonable grounds.

(3) The purpose of an investigation must be to-

(a) establish as many as possible of the relevant facts;

(b) identify, or facilitate the identification of, the perpetrators;

(c) establish whether any relevant action or omission by a public authority was lawful (including, in particular, whether any deliberate use of force was justified in the circumstances);

(d) establish whether any action or omission of a perpetrator was carried out with the knowledge or encouragement of, or in collusion with, a public authority;

(e) obtain and preserve evidence;

(f) identify material which is or may be relevant to motive (including, in particular, racial, religious or other sectarian motive);

(g) identify acts (including omissions; and including decisions taken by previous investigators or other public authorities) that may have prevented the death from being investigated or a perpetrator being identified or charged; and

(h) take any other action that the HIU thinks appropriate.

(4) In applying the founding principles of balance, fairness and equitableness the HIU must, in particular, investigate with equal rigour irrespective of whether suspected or alleged perpetrators were or were not public authorities.

(5) In giving effect to subsection (3)(d) the HIU must publish a policy on what amounts to collusion; and for that purpose-

(a) the policy must aim to reflect the discussions of the meaning of collusion in the Third Report of Sir John Stevens's inquiry into certain murders published on 17 April 2003 and in the Collusion Inquiry Report of Mr Justice Peter Cory printed by Order of the House of Commons on 1 April 2004 (HC 471),

(b) the policy must identify any other relevant definitions or observations made by judges or others that the HIU takes into account in forming the policy,

(c) the policy must, in particular, include aiding and abetting, and deliberate conspiracy, within the concept of collusion, and

(d) the policy must also, in particular, provide that a person ("P1") colludes in the act or omission of another ("P2") when-

(i) P1 would be able to make a report about, or take some other action in respect of, P2's act or omission, acting in P1's capacity as a member or official of a public authority (within the United Kingdom or elsewhere), and 
(ii) P1 takes no action in respect of P2's act or omission, or takes action which is not reasonably likely to be effective.

(6) The HIU must from time to time, at intervals of not more than one year, make a report to the Policing Board as to whether the HIU considers that the functions under this Part should be extended to include the investigation of serious troubles-related injuries; and if the HIU makes a recommendation for extension, the Secretary of State may by regulations-

(a) extend the functions of the HIU to the investigation of serious troubles-related injuries;

(b) define "troubles related" and "serious" in the context of injuries (and those definitions may make provision by reference to the opinion of the HIU);

(c) make consequential amendments of this Act.

\section{Cases falling within HIU's jurisdiction}

(1) The HIU may investigate the following classes of case-

(a) cases which have not been the subject of an investigation by another investigating body; and

(b) cases which have been the subject of an investigation by another investigating body, where-

(i) the investigation has not been completed;

(ii) the investigation has been completed, but the HIU has reason to believe that the investigation was or may have been flawed in some substantive or procedural respect (which may, in particular, include lack of independence);

(iii) the investigation has been completed, but the HIU has reason to believe that additional matters require to be investigated (whether as a result of the availability of new evidence or otherwise);

(iv) the investigation has been completed, but an interested person requests the HIU to re-investigate and the HIU thinks it appropriate to grant the request.

(2) The HIU may not investigate a case if-

(a) an investigation by another investigating body has been completed, and

(b) in the opinion of the HIU the case does not fall into a class described in subsection (1)(b)(ii) to (iv).

(3) The HIU may investigate a death whether or not it has been the subject of an inquest.

(4) For the purposes of this section "reason to believe" includes reason arising from a decision of a court or tribunal.

\section{Conduct of investigations}

\section{Priorities}

(1) In allocating resources to investigations the HIU must give priority to older cases.

(2) But subsection (1) does not apply where the HIU thinks the order of priority should be varied by reason of special circumstances.

(3) The HIU must from time to time, at intervals of not more than one year, provide a report to the Policing Board giving details of-

(a) the HIU's caseload since the previous report, and

(b) how the HIU has prioritised cases.

(4) In particular, the HIU may give priority to carrying out part of the investigation of a case if the HIU has reason to believe that it may not be possible to carry out that part of the 
investigation along with other aspects of the case at a later time (whether because of the age or health of a potential witness or for some other reason).

\section{Policing powers}

(1) For the purpose of conducting, or assisting in the conduct of, an investigation under this Part, an officer of the HIU has all the powers and privileges of a constable throughout Northern Ireland and the adjacent United Kingdom territorial waters.

(2) Section 32(3) of the Police (Northern Ireland) Act 2000 (interpretation) applies for the purposes of subsection (1).

(3) Section 66 of the Police (Northern Ireland) Act 1998 (offences) applies to a person to whom subsection (1) applies as it applies to a constable.

(4) A person to whom subsection (1) applies is not to be treated as being in police service for the purposes of-

(a) Article 145 of the Trade Union and Labour Relations (Northern Ireland) Order 1995; or

(b) Article 243 of the Employment Rights (Northern Ireland) Order 1996.

(5) The Department of Justice in Northern Ireland must by order provide that any provision of the Police and Criminal Evidence (Northern Ireland) Order 1989 which relates to investigation of offences conducted by police officers (within the meaning of that Order) is to apply, subject to such modifications as the order may specify, to investigations under this Part conducted by persons who are not police officers (within the meaning of that Order).

\section{Reports of investigations' conclusions}

\section{Report to DPPNI}

(1) When the HIU completes an investigation which concerns the commission of a crime it must as soon as reasonably practicable provide a report of the findings (a "prosecution report") to the Director of Public Prosecutions for Northern Ireland ("DPPNI").

(2) The HIU must-

(a) before providing a prosecution report, consult the DPPNI about any evidential issues appearing to the HIU to arise, and

(b) reflect the results of that consultation in the prosecution report.

(3) A prosecution report must include disclosure of all information that is or could be relevant to the decision as to what action, if any, to take as a result of the investigation.

(4) The DPPNI must ensure that consideration of and decisions in connection with a prosecution report are taken without the involvement of any person who was involved in any capacity in any aspect of previous consideration of, or decisions in relation to-

(a) the same case, or

(b) a case concerning some or all of the same people.

(5) In relation to decisions arising from a HIU investigation to-

(a) discontinue proceedings under section 32 of the Justice (Northern Ireland) Act 2002, or

(b) apply the public interest test under the Code for Prosecutors issued further to section 37 of the Justice (Northern Ireland Act 2002,

the DPPNI may not decline to prosecute solely on the grounds that the alleged perpetrator was or may have been acting (or purporting to act) on behalf of a public authority.

\section{Report to deceased's family}

(1) When the HIU completes an investigation of a death it must as soon as reasonably practicable provide a report of the findings to the deceased's family (a "family report"). 
(2) For that purpose "family" means persons who the HIU thinks it is appropriate to treat as the family of the victims; including, as a general rule-

(a) spouses and partners,

(b) former spouses and partners,

(c) parents,

(d) children

(e) siblings, and

(f) any person whom the HIU thinks had a relationship of a family character with the victim.

(3) A family report must include as much information about the investigation and its findings as the HIU believes can be made public without prejudicing the administration of justice.

(4) In particular, a family report must set out the HIU's conclusions on-

(a) the matters specified in section 10(3)(c) and (d) (lawfulness and collusion);

(b) whether the actions investigated had or may have been wholly or partly motivated by racial, religious or other sectarian factors;

(c) whether the actions investigated were or may have been connected with other offences or actions (whether or not already investigated);

\section{Report to other victims' families}

(1) When the HIU completes an investigation of a death it must as soon as reasonably possible prepare a report (an "other victims report") which it must make available on request to other victims or their families.

(2) For that purpose-

(a) "other victims" means persons who the HIU thinks were killed or injured in the course of the actions considered by the investigation, and

(b) "family" has the same meaning as in section 15(2).

17 Other reports

(1) At any stage during an investigation, the HIU may make interim reports available pending the production of the reports under sections 15 and 16.

(2) The HIU must from time to time, at intervals of not more than one year, provide a report to the Implementation and Reconciliation Group-

(a) recommending themes to be examined by the IRG, and

(b) specifying patterns emerging in information before the HIU which provide the basis for recommendations under paragraph (a).

\section{Public statements}

The HIU may make a public statement about the results of an investigation.

\section{Non-publication of information putting lives at risk}

(1) This section applies to a report or statement under sections 15 to 18.

(2) The HIU may omit information from a report or statement if satisfied that inclusion of the information would put an individual's life at risk.

(3) The Director of the HIU-

(a) must designate staff with responsibility for assessing whether subsection (2) should apply in particular cases (and those staff must have operational independence from staff carrying out investigations), and 
(b) must make decisions under subsection (2) personally, having regard to the recommendations of the designated staff.

\section{Relationship with other bodies}

\section{Other investigations}

(1) If the HIU notifies an investigating body that the HIU is investigating a case, the investigating body may not begin or continue any investigation into that case.

(2) If the Police Ombudsman for Northern Ireland receives a complaint which in the Ombudsman's opinion could be investigated by HIU-

(a) the Ombudsman must refer to the complaint to the HIU for investigation;

(b) if the HIU thinks it does not have jurisdiction to investigate the complaint, it must decline the referral and the Ombudsman may investigate.

\section{International obligations}

(1) The Secretary of State may by regulations make provision designed to facilitate compliance with obligations entered into-

(a) by the United Kingdom in respect of cross-border troubles-related deaths or breaches, or

(b) by the government of another State in respect of cross-border troubles-related deaths or breaches.

(2) A death or breach is "cross-border" if an act or omission that was or may have been committed in connection with the death or breach occurred or may have occurred outside the United Kingdom.

(3) Regulations may, in particular-

(a) permit or require the HIU to cooperate with a specified organisation outside the United Kingdom;

(b) permit or require the HIU to disclose information to a specified organisation outside the United Kingdom.

(4) Regulations may make incidental and consequential provision including, in particular, provision modifying the effect of this Act where the Secretary of State thinks it necessary or expedient for the purpose of facilitating compliance with obligations of the kind specified in subsection (1)(a) or (b).

\section{Disclosure to HIU}

(1) A public authority must comply, within such period as the Director of the HIU thinks reasonable, with a request of the HIU, for the purpose of an investigation under section 10 , to-

(a) provide information to the HIU;

(b) allow the HIU to access information kept by the public authority.

(2) The HIU must include a unit consisting of members of staff with responsibility for accessing records kept by other public authorities (and those staff must have appropriate training in confidentiality and the rules of onward disclosure).

(3) A duty or power under this Act to disclose information to the HIU, or to provide access to information for the HIU, has effect despite any provision of-

(a) the Data Protection Acts,

(b) the Freedom of Information Act 2000,

(c) the Official Secrets Acts,

(d) the Regulation of Investigatory Powers Act 2000, or

(e) any other enactment. 
(4) A duty or power under this Act to disclose information to the HIU, or to provide information for the HIU, overrides legal professional privilege in respect of advice given to a public authority (but not in respect of advice given to an individual in a personal capacity).

(5) The duty under subsection (1) has effect despite any obligation of confidentiality or other limitation on disclosure (including an obligation or limitation imposed by or by virtue of an enactment).

(6) Where the HIU thinks that a document or class of document, or material of a specified description or class, might become the subject of a request under subsection (1) or a power or duty under this Part, the HIU may direct that it must not be destroyed, damaged or altered; and a public authority must comply with a direction.

\section{Transfer of legacy files}

(1) The Police Service of Northern Ireland must as soon as reasonably practicable transfer to the HIU-

(a) all files of the Historical Enquiries Team, and

(b) all other information relating to the investigation of matters falling with the jurisdiction of the HIU.

(2) On transfer the HIU is responsible for the management of the files (including disclosure) in a manner that is compatible with the Convention Rights (within the meaning of the Human Rights Act 1998); and, as soon as is reasonably practicable after transfer, the HIU must notify the Police Service of Northern Ireland of the arrangements made by the HIU for that purpose.

(3) The Police Ombudsman for Northern Ireland must as soon as reasonably practicable transfer to the HIU all files relating to the investigation of matters falling with the jurisdiction of the HIU.

\section{Failure to cooperate}

(1) It is an offence for a person to fail to comply with a duty under this Part to-

(a) disclose information to the HIU, or

(b) provide access to information for the HIU.

(2) It is an offence for a person to conceal, alter or destroy information where the person knows or ought to have known that the information was or might have been relevant to an investigation that the HIU was conducting or might wish to conduct.

(3) An offence under this section is punishable on summary conviction with a fine.

(4) An offence under this section may be committed by an organisation or by an officer or employee of an organisation (or both).

\section{Referrals from the DPPNI}

The HIU must, at the request of the DPPNI, ascertain and give to the DPPNI-

(a) information about a troubles-related death or qualifying human rights breach appearing to the DPPNI to need investigation on the ground that it may involve an offence committed against the law of Northern Ireland, and

(b) information appearing to the DPPNI to be necessary for the exercise of the DPPNI's functions.

\section{Disclosure to the ICIR}

(1) The HIU shall provide copies of such information as is requested by the Independent Commission on Information Retrieval ("ICIR") in the exercise of its functions. 
(2) In order to facilitate the disclosure provided for in subsection (1), the HIU shall make such arrangements to ensure that-

(a) the HIU disclosure unit referred to in section 22(2) is responsible for providing such information;

(b) no other HIU staff (including investigators) are aware of the content of any request of information from the ICIR.

\section{Duties to cooperate with the Coroner}

(1) The HIU shall comply with any request of the Coroner to provide information in connection with legacy inquests.

(2) The HIU shall ensure that the HIU disclosure unit referred to in section 22(2) is responsible for providing such information.

(3) The HIU shall establish a Coroner's team to provide investigative services to the Coroner in relation to legacy inquests.

(4) The HIU Director shall ensure the Coroner's team-

(a) is operationally separate from other HIU investigations;

(b) complies with requests from the Coroner for investigative support in connection with inquests into troubles-related deaths;

(c) provides support in a manner that appears to the HIU Director to be appropriate for legacy inquests;

(d) complies with the Convention rights.

(5) In this section "legacy inquests" means inquests into troubles-related deaths.

\section{Oversight by the Policing Board}

(1) The Police (Northern Ireland) Act 2000 is amended as follows.

(2) In section 3 (general functions of the Board), after subsection (3B) insert"(3C) The Board shall-

(a) monitor the exercise of the functions of the Historical Investigations Unit ("HIU”);

(b) assess the level of public satisfaction with the performance of the HIU;

(c) make arrangements for encouraging the co-operation of the public with the HIU."

(3) In section 33A (provision of information to Board), after subsection (8) insert-

"(9) This section applies to the Director of the Historical Investigations Unit ("HIU”) as it applies to the Chief Constable.

In the application of this section to the Director of the HIU-

(a) each reference to the Chief Constable is to be read as a reference to the Director of the HIU;

(b) the reference in subsection (1) to the exercise of any of the Board's functions is to be read as a reference to the exercise of any of the Board's functions in relation to the HIU."

(4) In section 76A (disclosure of information and holding of inquiries) after subsection

(6) insert-

"(7) In relation to disclosure by the HIU the grounds specified in subsection (1)(a) do not apply."

(5) In section 57 (annual and other reports by the Board) in subsection (2), after paragraph (m) insert- 
"(n) the exercise of the functions of the HIU;

(o) the level of public satisfaction with the performance of the HIU;

(p) the effectiveness of arrangements made under section 3(3C)(c) for obtaining the cooperation of the public with the HIU."

(6) In section 59 (general duty of Chief Constable to report to Board), after subsection (11) insert-

"(12) The Director of the HIU shall report to the Board on request as to-

(a) how the Director intends a function of the HIU to be exercised; or

(b) whether the exercise of function was in accordance with that intention.

(13) Subsections (2) to (5), but not subsection (3)(a), apply to a report under subsection (12).

(14) In the application of subsections (2) to (5) to a report under subsection (12), each reference to the Chief Constable is to be read as a reference to the Director of the HIU."

(7) In section 60 (inquiry by Board following report by Chief Constable), after subsection (20) insert-

"(21) Where the Board-

(a) has considered a report on any relevant HIU matter submitted by the HIU Director under section 59, and

(b) considers that an inquiry ought to be held under this section into that matter or any related matter disclosed in the report by reason of the gravity of the matter or exceptional circumstances, the Board may, after consultation with the HIU Director, cause such an inquiry to be held.

(22) Subsections (2) to (17) of this section apply to an inquiry which the Board causes to be held under subsection (21) as they apply to an inquiry caused to be held under subsection (1).

(23) In the application of subsections (2) to (17) to an inquiry which the Board causes to be held under subsection (21) -

(a) each reference to the Chief Constable (except the reference in subsection (16)(a)) is to be read as a reference to the HIU Director;

(b) subsection (16) is to be read as including a requirement to send a copy of the report of any inquiry to the HIU Director (as well as to the persons in subsection (16)(a) to (d))."

(8) In Part 6 of Schedule 1 (procedure of the Northern Ireland Policing Board), after paragraph $19 \mathrm{~A}$ insert-

"Attendance of HIU Director at meetings

19B.-(1) The Director of the HIU must attend a meeting of the Board if the Board gives the Director reasonable notice.

(2) The HIU Director may not be given notice under this paragraph of a meeting that is to be held in accordance with-

(a) paragraph 18, except where section 60 applies in relation to a) a report on any relevant HIU matter submitted by the HIU Director under section 59, or

(b) paragraph 19." 


\section{Inspection of the HIU}

(1) In section 46(1) of the Justice (Northern Ireland) Act 2002 (Chief Inspector of Criminal Justice in Northern Ireland: organisations to be inspected) after paragraph (u) insert-

"(v) The Historical Investigations Unit ("HIU”)."

(2) In section 49 of the Justice (Northern Ireland) Act 2002 (reports) for subsection (1A) substitute-

"(1A) In this section "protected information" means-

(a) in relation to inspections of the HIU, information the inclusion of which in a report would put an individual's life at risk, and

(b) in any other case, information the inclusion of which in a report would be against the public interest on the ground of national security."

(3) In section 54 of the Police Act 1996 (appointment and functions of inspectors of constabulary) after subsection (2BA) insert-

"(2C) The Northern Ireland Policing Board may request the inspectors of constabulary to carry out an inspection into the Historical Investigations Unit; and a request under this subsection may include a request for the inspection to be confined to specfied matters of that Unit."

(4) In section 55 of the Police Act 1996 (publication of reports) after subsection (2A) insert-

"(2B) In relation to reports under section 54 (2C) the grounds specified in subsection (2)(a) do not apply."

(5) In section 55 of the Police Act 1996 (publication of reports) after subsection (7) insert“(8)In this section in relation to reports under section $54(2 \mathrm{C})$ -

(a) references to the local policing body mean the Northern Ireland Policing Board, and

(b) references to the Chief Officer of Police means the Director of the Historical Investigations Unit."

\section{HIU Complaints}

In the Police (Northern Ireland) Act 1998 (c 32)—after section 60ZB insert-

\section{“60ZC Historical Investigations Unit}

(1) In relation to the exercise of specified powers the Ombudsman and the Director of the Historical Investigations Unit (HIU) shall, with the approval of the Policing Board, establish procedures corresponding or similar to any of those established by virtue of this Part.

(2) "Specified powers" means the policing powers exercised by officers of the HIU provided for under section 13 of the [Model Implementation Bill] and specified in an agreement under subsection (1)."

In section 61(5) (reports), at the end of paragraph (b) insert"; and if the report concerns the HIU, to the HIU."

\section{Finance of external bodies supporting HIU functions}

(1) In relation to the functions discharged by the bodies referred to in sections 27 to 30 in relation to the HIU, the Treasury must determine amounts to be paid to or in respect of expenses incurred in the discharge of functions in this section.

(2) Amounts paid under subsection (1) and are to be charged on, and paid out of, the Consolidated Fund. 


\section{PART 3}

\section{INDEPENDENT COMMISSION ON INFORMATION RETRIEVAL}

\section{Establishment}

(1) In this Act "the ICIR" means an independent organisation established by an agreement ("the Founding Agreement"), made in connection with the affairs of Northern Ireland between Her Majesty's Government in the United Kingdom and the Government of the Republic of Ireland, to establish an Independent Commission on Information Retrieval to enable victims to seek and privately receive information about troubles-related deaths of members of their families.

(2) The text of the Founding Agreement is set out in Schedule 2.

(3) The Secretary of State and the First Minister and Deputy First Minister shall take any necessary steps and make any necessary arrangements to-

(a) ensure that the ICIR has the independence and autonomy provided for in the Founding Agreement, and

(b) comply with the obligations of Her Majesty's Government in the United Kingdom under the Founding Agreement.

(4) This section shall come into force on such day as the Secretary of State, after consulting the Minister for Justice and Equality of the Republic of Ireland, may by order made by statutory instrument appoint.

(5) This section and sections 33 to 35 shall cease to have effect at the end of the period of five years beginning with the date on which this section comes into force; but-

(a) the Secretary of State, after consulting the Minister for Justice and Equality of the Republic of Ireland, may by order made by statutory instrument extend or revive this section and sections 33 to 35 for a period specified in the order, and

(b) an order under this subsection may include such transitional provisions as appear to the Secretary of State to be expedient.

(6) The Secretary of State shall make regulations for the decommissioning of the ICIR in accordance with this section; and the regulations must, in particular-

(a) incorporate arrangements determined by the Commission for the archives to be maintained and protected from disclosure for the period of 50 years beginning with the date on which this section ceases to have effect, and

(b) provide for or continue provision for offences or other provisions designed to ensure that persons engaged in the work of the ICIR do not disclose information obtained by the ICIR.

\section{Capacity, immunities and finance}

(1) The Secretary of State may by regulations-

(a) confer on the ICIR the legal capacities of a body corporate;

(b) confer on the ICIR, in such cases, to such extent and with such modifications as the regulations may specify, any of the privileges and immunities set out in Part I of Schedule 1 to the International Organisations Act 1968 (and the regulations must, in particular, provide immunity from proceedings for judicial review);

(c) confer on members and servants of the ICIR and members of their families who form part of their households, in such cases, to such extent and with such modifications as the regulations may specify any of the privileges and immunities set out in Parts II, III and V of that Schedule;

(d) make provision about the waiver of privileges and immunities. 
(2) In subsection (1) "servants of the ICIR" includes agents of, and persons carrying out work for or giving advice to, the ICIR.

(3) Regulations under subsection (1) -

(a) may make different provision for different cases (including different provision for different persons);

(b) shall be made by statutory instrument which shall be subject to annulment in pursuance of a resolution of either House of Parliament.

(4) The Secretary of State must-

(a) make payments to the ICIR or to members of the ICIR;

(b) provide for the ICIR such premises and facilities, and the services of such staff, as the Secretary of State thinks appropriate;

(c) defray expenses of the ICIR in accordance with the Founding Agreement; and

(d) as soon as reasonably practicable after the commencement of this section, publish arrangements for the matters specified in paragraphs (a) to (c) that comply with any requirements of the Funding Agreement for ensuring the operational independence of the ICIR.

(5) Amounts paid or incurred by virtue of this section are to be charged on, and paid out of, the Consolidated Fund.

\section{4 "Victims and survivors"}

(1) In this Part "victims and survivors" means the family of deceased persons whose deaths were troubles-related.

(2) For that purpose "family" means persons who the ICIR thinks it is appropriate to treat as the family of the deceased; including, as a general rule-

(a) spouses and partners,

(b) former spouses and partners,

(c) parents,

(d) siblings,

(e) children, and

(f) any person who the ICIR thinks had a relationship of a family character with the deceased.

\section{The work of the ICIR}

(1) The Secretary of State must make regulations conferring immunities or other protection on persons in respect of or in connection with communication or cooperation with the ICIR.

(2) The Secretary of State must make regulations enabling the ICIR to require all public authorities (including the HIU) to provide information.

(3) Information provided to the ICIR is not admissible as evidence in criminal or civil legal proceedings.

(4) The Secretary of State must make regulations about information provided to the ICIR that is designed to amplify or give effect to subsection (3), and to give effect to provisions of the Founding Agreement about-

(a) confidentiality and non-disclosure, and

(b) inadmissibility in criminal and civil proceedings, and

(c) ensuring that a person providing information does not become liable to criminal or civil proceedings, or administrative sanctions, by reason only of providing the information. 
(5) The Secretary of State must make regulations prohibiting-

(a) the provision of false information to the Commission by a person who knows the information to be false;

(b) obstruction of the work of the ICIR (including the destruction by public authorities of information likely to be required by the ICIR);

(c) the disclosure of information by members or staff of the ICIR in contravention of regulations under subsection (4)(a).

(6) Regulations under this section-

(a) may apply an existing enactment with or without modifications;

(b) may confer a discretionary function;

(c) may create an offence.

(7) The ICIR must conduct its proceedings in accordance with any Code of Practice adopted and published by it.

\section{PART 4}

\section{IMPLEMENTATION AND RECONCILIATION GROUP}

\section{Definitions}

\section{Definitions}

In this Part-

(a) "the IRG" has the meaning given by section 37(1);

(b) "the IRG analysts" means the research analysts and experts engaged by the IRG to compile the evidence base;

(c) "the academic experts" means the independent academic experts commissioned by the IRG to produce the report on themes;

(d) "the archives" means the Oral History Archive ("the OHA") and other existing oral history archives with which the OHA works in accordance with section 63(1);

(e) "the evidence base" means the evidence base established by the IRG to facilitate the report on themes;

(f) "information recovery" means the process conducted by the ICIR to enable victims to seek and privately receive information about troubles-related deaths of members of their families;

(g) "the legacy institutions" means the HIU, the ICIR and the OHA;

(h) "the report on themes" means the report on themes commissioned by the IRG from the academic experts;

(i) "Stormont House Agreement" means the agreement between the political leaders of Northern Ireland, the Government of the United Kingdom and the Government of the Republic of Ireland published on 23 December 2014;

(j) "themes" means patterns and themes relating to or arising from the political conflict in Northern Ireland;

(k) "the two Governments" means the Government of the United Kingdom and the Government of the Republic of Ireland.

\section{Nature, status and organisation}

\section{Establishment}

(1) There shall be a body corporate to be known as the Implementation and Reconciliation Group ("the IRG"). 
(2) The members of the IRG shall be appointed as soon as practicable after the entry into force of this section and in accordance with nominations under this section.

(3) The IRG shall consist of 11 members nominated in accordance with the following provisions.

(4) The First Minister and Deputy First Minister shall nominate as Chair of the IRG a person who appears to them to be independent and of international standing.

(5) Of the other members-

(a) three shall be nominated by the Democratic Unionist Party;

(b) two shall be nominated by Sinn Fein;

(c) one shall be nominated by the Social Democratic and Labour Party;

(d) one shall be nominated by the Ulster Unionist Party;

(e) one shall be nominated by the Alliance Party;

(f) one shall be nominated by the Government of the United Kingdom of Great Britain and Northern Ireland; and

(g) one shall be nominated by the Government of the Republic of Ireland.

(6) A person who in the opinion of the First Minister and Deputy First Minister, acting jointly, holds a public elected position, shall not be eligible for appointment as a member of the IRG.

(7) The First Minister and Deputy First Minister, acting jointly, shall encourage the persons responsible for making nominations to work together (in accordance with their respective domestic laws) with the aim of ensuring a gender-balance within the IRG.

(8) The First Minister and Deputy First Minister, acting jointly, shall encourage the persons responsible for making nominations to ensure that each member-

(a) has qualities and experience which are likely to command the respect and confidence of all those dealing with the IRG, including victims and other bodies concerned with troubles-related deaths;

(b) will act independently and impartially as a member of the IRG, free from any political interference;

(c) has experience and skills which are relevant to the functions of the IRG;

(d) neither has nor expects to have any financial or other interests that are reasonably likely to conflict with the exercise of the functions of a member.

\section{Chair of the IRG}

(1) The Chair of the IRG shall be appointed for the duration of the IRG, subject to the provisions of this section.

(2) If the Chair resigns by notice in writing to the First Minister and Deputy First Minister, they shall appoint a replacement as soon as reasonably practicable.

(3) If the First Minister and Deputy First Minister are satisfied that the Chair is no longer able, willing or fit to perform the functions of the office, they may dismiss the Chair; and they shall appoint a replacement as soon as reasonably practicable.

(4) For the purposes of subsection (3) -

(a) a person is no longer fit to perform the functions of the Chair if, in particular, the person no longer satisfies the criteria for appointment set out in section 37(8); and

(b) before the First Minister and Deputy First Minister dismiss the Chair under subsection (3), they must consult the Secretary of State.

(5) Proceedings of the IRG shall not be invalidated by reason of a vacancy or irregularity in the office of Chair. 


\section{Other Members of the IRG}

(1) Members of the IRG, other than the Chair, shall be nominated for a term of three years, which shall be renewable, subject to subsection (2).

(2) Upon completion of the mandate of the IRG, the appointment of any remaining members lapses.

(3) If a member resigns by notice in writing to the body who nominated the member in accordance with section 37(5), that body shall nominate a replacement as soon as reasonably practicable.

(4) If the Chair considers that a member is no longer able, willing or fit to perform the functions of the office, the Chair may dismiss that member; and the original nominating body shall nominate a replacement as soon as reasonably practicable.

(5) For the purposes of subsection (4) -

(a) a person is no longer fit to perform the functions of the office of a member if the person no longer satisfies the criteria for appointment set out in section 37(8); and

(b) before the Chair dismisses a member under subsection (4), the Chair must consult the First Minister and Deputy First Minister and the original nominating body.

(6) Proceedings of the IRG shall not be invalidated by reason of a vacancy or irregularity in the membership.

\section{Remuneration and allowances}

The Chair, in consultation with the First Minister and Deputy First Minister and the two Governments, shall determine the terms of appointment of members including, in particular, whether members shall work for the IRG on a full-time or part-time basis (according to the requirements of the IRG from time to time).

\section{Secretariat}

(1) The IRG shall appoint a Secretariat to provide professional and administrative support to the IRG, including the IRG analysts.

(2) The IRG shall appoint the Chief Executive and other staff of the secretariat.

(3) In appointing staff the IRG shall aim to ensure that each member of the Secretariat satisfies the principles set out in section 37(8) in respect of members of the IRG.

(4) Staff may be (but need not be) appointed on secondment from a public authority.

\section{Funding}

(1) The Treasury must determine-

(a) amounts to be paid to or in respect of the Chair of the IRG and other members (by way of or in respect of remuneration, allowances and pension), and

(b) maximum amounts of expenditure by the Chair of the IRG in respect of staff and administration.

(2) Amounts paid under subsection (1)(a) and amounts of expenditure incurred under subsection 1(b) are to be charged on, and paid out of, the Consolidated Fund.

\section{Annual report}

(1) The IRG shall publish at intervals not less than a year a report on its activities.

(2) The report may-

(a) include recommendations to groups and bodies in Northern Ireland, including the legacy institutions, and to the two Governments for further work on implementation and reconciliation within the scope of its mandate;

(b) comment on the level of co-operation between the legacy institutions. 


\section{Governance}

(1) Subject to subsection (2), the IRG shall take decisions by a simple majority of its members present and voting.

(2) The approval of at least seven members of the IRG shall be required for the decision to commission the report on themes.

\section{Duration}

(1) The IRG shall exercise its functions, or as many of them as have not otherwise expired, until the end of the period of six months beginning with the date of publication of the report on themes.

(2) The Secretary of State may by regulations made by statutory instrument amend subsection (1) so as to increase the length of the specified period.

Objective and functions

\section{Objective and functions}

The IRG shall-

(a) oversee the archives and information recovery so as to ensure fulfilment of the objectives of the Stormont House Agreement;

(b) at the end of the period of five years beginning with the date of publication of the Stormont House Agreement, commission a report on themes and oversee its production;

(c) encourage and support other initiatives which contribute to reconciliation, better understanding of the past and reducing sectarianism; and

(d) encourage consideration of statements of acknowledgement from any individual or group or body participating in the conflict in Northern Ireland, including the two Governments.

\section{Exercise of functions}

(1) The IRG shall have full independence (including complete operational autonomy).

(2) The IRG shall conduct the process of the report on themes with sensitivity and rigorous intellectual integrity, devoid of any political interference.

(3) The IRG shall conduct its proceedings in accordance with any Code of Practice adopted and published by it.

\section{Relationship with other bodies}

\section{Relationship with other bodies}

(1) To facilitate its oversight of themes, archives and information recovery, the IRG shall at intervals not less than a year receive separately from the OHA and the ICIR a report-

(a) suggesting themes for analysis, and

(b) describing the progress of the work of the institution.

(2) Upon receipt of the report in subsection (1), the IRG may make recommendations to the OHA and the ICIR as to their future activities.

\section{Report on themes}

\section{Report on themes}

(1) In accordance with section 46(b) the IRG shall commission the report on themes from academic experts.

(2) The IRG shall decide the themes to be included in the report, after consultation with-

(a) the legacy institutions; and

(b) victims and organisations representing their interests. 
(3) The academic experts must, in the opinion of the IRG-

(a) be of proven academic standing in their field;

(b) be capable of and committed to acting with sensitivity and rigorous intellectual integrity;

(c) be capable of and committed to acting independently, free from any political interference.

(4) The IRG may commission the report on themes with a flexible structure so that-

(a) different academic experts or groups of experts may work on separate themes;

(b) studies of separate themes may constitute separate sections of a composite report.

(5) The IRG shall aim to ensure completion of the report on themes within three years of its commission.

(6) The IRG shall aim to publish the report on themes within one year after its completion.

(7) In the context of the publication of the report, the IRG shall consider making recommendations for activities of outreach and reconciliation, including statements of acknowledgement.

\section{Evidence base}

(1) To facilitate the report on themes, the IRG shall prepare an evidence base.

(2) The IRG may engage suitably qualified and vetted research analysts and other experts to compile the evidence base.

(3) The legacy institutions shall provide the IRG analysts with reports and summaries of cases and access to other data relevant to the evidence base.

(4) The evidence base may include both open source and confidential material.

(5) Where the legacy institutions pass confidential information to the IRG analysts, those institutions may specify conditions as to its storage, use and publication.

(6) The IRG may enter into agreements with other public authorities in respect of the provision of information.

(7) The two Governments shall facilitate the provision of information relevant to the evidence base.

\section{PART 5}

\section{ORAL HISTORY ARCHIVE}

\section{Definitions}

\section{Definitions}

In this Part -

(a) "collectors" means persons collecting oral history material on behalf of the OHA;

(b) "contributors" means persons contributing oral history material to the OHA;

(c) "the OHA" has the meaning given by section 52(2);

(d) "oral history material" includes recordings of interviews and related documentation;

(e) "PRONI" means the Public Records Office of Northern Ireland;

(f) "the Secretariat" means the Secretariat of the OHA established in accordance with section 60 ;

(g) "Stormont House Agreement" means the agreement between the political leaders of Northern Ireland, the Government of the United Kingdom and the Government of the Republic of Ireland published on 23 December 2014; 
(h) "the Troubles" means the troubles which occurred in or after 1966 as a result of or in connection with political conflict in Northern Ireland;

(i) "the two Governments" means the Government of the United Kingdom and the Government of the Republic of Ireland.

\section{Establishment and operation}

\section{Establishment}

(1) The First Minister and Deputy First Minister, acting jointly, shall establish a resource designed to provide a central place for people from all backgrounds throughout the United Kingdom and Ireland to share experiences and narratives related to the Troubles.

(2) The resource shall be known as the Oral History Archive (and in this Part is referred to as the OHA).

(3) The First Minister and Deputy First Minister, acting jointly, shall determine the location of the OHA.

\section{Principles of operation}

(1) The First Minister and Deputy First Minister, acting jointly, shall make arrangements to ensure that the OHA operates independently, free from political interference, in accordance with the Stormont House Agreement.

(2) The OHA shall have regard to the founding principles in the exercise of its functions.

\section{Code of Practice}

(1) The OHA shall prepare and publish, in consultation with relevant stakeholders, a nonstatutory Code of Practice to provide guidance on the exercise of its functions in accordance with international best practice.

(2) The Code of Practice must, in particular-

(a) include a Code of Ethics which will regulate the collection of oral history material and rights and safeguards for contributors;

(b) outline appropriate measures to facilitate contributions from victims and survivors;

(c) require the OHA to take reasonable steps to protect information that appears to the OHA to be sensitive or confidential, within the limits of the law;

(d) require OHA staff to ensure that collectors and contributors are made aware that oral history material may be admissible as evidence in criminal or civil legal proceedings (including proceedings initiated by the HIU);

(e) include provision designed to ensure that contributors and collectors appreciate the potential legal consequences of providing information.

Nature and status

\section{Capacity}

The Secretary of State may by regulations confer on the OHA the legal capacities of a body corporate.

\section{Immunity from suit}

(1) No action lies against a person who is -

(a) a member of the Executive Board of the OHA;

(b) a member of the Advisory Board of the OHA;

(c) a member of the Secretariat or other staff of the OHA;

(d) an agent of, or a person carrying out work for or giving advice to, the OHA,

in respect of any act or omission occurring in the execution or purported execution of the person's functions in connection with the OHA (but not an act or omission in bad faith). 
(2) For the purposes of the law of defamation, qualified privilege under Part 1 of Schedule 1 of the Defamation Act 1996 attaches to-

(a) any statement made by a contributor by way of contribution to the OHA; and

(b) any record or publication of that statement by the OHA.

\section{Governance}

\section{Appointment of Executive Board and Advisory Board}

(1) The OHA shall be governed by an Executive Board, assisted by an Advisory Board.

(2) The Executive Board shall consist of three executive Directors.

(3) The Chair of the Executive Board and one other executive Director shall be appointed by the First Minister and Deputy First Minister, acting jointly.

(4) One Executive Director shall be appointed by the Secretary of State, in consultation with the Government of the Republic of Ireland.

(5) The Advisory Board shall assist the Executive Board by commenting on strategy and policy, recommending objectives and priorities, overseeing complaints, ensuring financial supervision and submitting annual reports to the IRG.

(6) The Advisory Board shall consist of seven members, of which-

(a) the Chair shall be appointed by the First Minister and Deputy First Minister, acting jointly, in consultation with the two Governments;

(b) three members shall be appointed by the First Minister and Deputy First Minister;

(c) one member shall be appointed by the Secretary of State;

(d) one member shall be appointed by the Secretary of State, in consultation with the Government of the Republic of Ireland;

(e) one member shall be the Deputy Keeper of the PRONI ex officio.

(7) Persons appointing or nominating members of the Executive Board and the Advisory Board shall aim to appoint or nominate persons who-

(a) have experience of-

(i) the management of public bodies;

(ii) the administration of archives;

(iii) the practice of oral history;

(iv) relevant academic work; or

(v) working with victims and survivors;

(b) have qualities which are likely to command the respect and confidence of contributors and other persons likely to engage with the OHA, including victims and survivors;

(c) are impartial, and perceived to be impartial, by contributors and other persons likely to engage with the OHA, including victims and survivors;

(d) have experience and skills which will assist the OHA in handling sensitive information and making judgements about the circumstances and timing of contributions being made public;

(e) neither have nor expect to have any financial, professional or other interests that are reasonably likely to conflict with the exercise of their functions.

(8) The Secretary of State, and the First Minister and Deputy First Minister, acting jointly, shall encourage the persons responsible for making appointments and nominations to work together (in accordance with their respective domestic laws) with the aim of ensuring a gender-balance within the OHA. 


\section{Tenure of Executive Directors}

(1) In this section "Director" means an Executive Director of the OHA.

(2) The appointment of a Director is for five years, subject to the following provisions, and may be renewed.

(3) Where an Executive Director resigns by notice in writing to the person who appointed the Director, that person shall appoint a replacement as soon as is reasonably practicable.

(4) If the First Minister and Deputy First Minister, acting jointly, are satisfied that a Director is no longer able, willing or fit to perform the functions of the office, they may dismiss the Director (and a replacement shall be appointed as soon as is reasonably practicable in the same manner as the original appointment).

(5) For the purposes of subsection (4) a person is no longer able or fit to perform the functions of the office of Director if, in particular, the person no longer satisfies the criteria for appointment set out in section 57(7).

(6) The validity of proceedings of the OHA shall not be affected by a vacancy in the office of Director or by an irregularity in the appointment of a Director.

\section{Tenure of members of Advisory Board}

(1) In this section "member" means a member of the Advisory Board of the OHA.

(2) The appointment of a member is for five years, subject to the following provisions, and may be renewed.

(3) Where a member resigns by notice in writing to the person who appointed the member, that person shall appoint a replacement as soon as is reasonably practicable.

(4) If the First Minister and Deputy First Minister, acting jointly, are satisfied that a member is no longer able, willing or fit to perform the functions of the office, they may dismiss the member (and a replacement shall be appointed as soon as is reasonably practicable in the same manner as the original appointment).

(5) For the purposes of subsection (4) a person is no longer able or fit to perform the functions of the office of member if, in particular, the person no longer satisfies the criteria for appointment set out in section 57(7).

(6) The validity of proceedings of the OHA shall not be affected by a vacancy in the office of a member or by an irregularity in the appointment of a member.

\section{Secretariat}

(1) There shall be a Secretariat to provide research, archival, interviewing and other professional and administrative support to the OHA.

(2) The Executive Directors shall appoint the staff of the OHA.

(3) In appointing staff the Executive Directors shall aim to ensure that the Secretariat has experience and knowledge of-

(a) the potential for memory to provoke psychosocial and traumatic harm;

(b) gender sensitivity;

(c) handling sensitive information and making judgments about its suitability for public release; and

(d) the need to satisfy the principles set out in section 57(7) above.

(4) Staff may be (but need not be) appointed on secondment from a public authority, including PRONI. 


\section{Finance}

\section{Remuneration and allowances}

(1) The Executive Directors shall be paid such remuneration and allowances as the First Minister and Deputy First Minister, acting jointly shall specify.

(2) The Executive Directors shall determine the remuneration and allowances of staff of the OHA subject to the provisions of section 62(1).

\section{Funding}

(1) The Secretary of State must, in consultation with the Executive Directors of the OHA-

(a) make payments to the OHA or to staff of the OHA;

(b) make payments of expenses to the members of the Advisory Board;

(c) provide for the OHA such premises and facilities, and the services of such staff, as the Secretary of State thinks appropriate;

(d) defray expenses of the OHA, including expenses of the Secretariat; and

(e) as soon as reasonably practicable after the commencement of this section, publish arrangements for the matters specified in paragraphs (a) to (d), together with a statement of the ways in which the arrangements ensure the operational independence of the OHA.

(2) Amounts paid or incurred by virtue of this section and section 61 are to be charged on, and paid out of, the Consolidated Fund.

Work of the $\mathrm{OHA}$

\section{The work of the OHA}

(1) The OHA shall aim to-

(a) collect from people from all backgrounds and from throughout the United Kingdom and Ireland new oral history material; and

(b) draw together and work with existing oral history projects.

(2) For the purpose of achieving the objectives in subsection (1), the OHA must-

(a) conduct research for the purpose of identifying priorities for the acquisition of new oral history material, taking full account of existing oral history collections;

(b) consult stakeholders (nationally and internationally) for the purpose of publicising the work of the OHA, refining priorities for the acquisition of oral history material, and securing the trust of a wide spectrum of contributors;

(c) consult victims and survivors and organisations representing their interests for the purposes of providing appropriate facilities and support in relation to their contributions to the OHA;

(d) establish, in consultation with the IRG, a policy for the acquisition of oral history material designed to further the cause of reconciliation and to secure the participation of people from all backgrounds and from throughout the UK and Ireland;

(e) provide a central training programme designed to train people from across the UK and Ireland to collect interviews in their communities and organisations for deposit in the OHA and to ensure that collectors comply with the Code of Practice;

(f) make arrangements for interviews to be conducted across the United Kingdom and Ireland;

(g) make arrangements for reviewing contributions, including the transcription of interviews; 
(h) make arrangements for follow-up with interviewees in order to finalise transcripts and the terms and conditions of the deposit;

(i) process and preserve recordings and relevant supporting data in a secure and confidential format;

(j) take all reasonable steps to safeguard contributions which are to be kept confidential;

(k) prepare and make available catalogues of oral history material;

(l) facilitate free public access to oral history material;

(m) make reports to the IRG at least annually about the progress of the OHA and identifying themes for consideration by the IRG.

(3) In pursuit of its aim of drawing together and working with other oral history projects, the OHA must-

(a) establish a comprehensive strategy for outreach to existing oral history projects;

(b) conduct research for the purpose of taking full account of other projects and liaising with stakeholders;

(c) appoint a designated member of the Secretariat to lead on this aspect of the work;

(d) offer the opportunity, where appropriate, to include in training programmes staff of existing oral history projects;

(e) provide technical support, including digitisation and the provision of digital copies in respect of contributions to the OHA;

(f) provide appropriate administrative support to enable the OHA, where appropriate, to accept, safeguard and provide access to existing oral history material concerning experiences and narratives related to the Troubles;

(g) to the fullest extent possible respect the terms of the original deposit and the wishes of existing oral history projects.

\section{Arrangements with PRONI}

The OHA and PRONI shall cooperate in making such arrangements as they see fit for the sharing of facilities, equipment and expertise.

\section{Engagement with contributors}

(1) In engaging with contributors the OHA shall take all reasonable steps to ensure that contributors understand that their engagement is voluntary and that they may withdraw from the process at any time.

(2) The OHA shall take all reasonable steps to ensure that contributors appreciate in advance potential legal consequences of engagement with the OHA.

(3) The OHA shall take all necessary steps to avoid identifying persons who have provided sensitive or confidential oral history material.

(4) The OHA will where possible provide all contributors with a copy of the final version of the oral history material which they have contributed.

\section{Handling of information}

\section{Obtaining and holding information}

(1) The OHA shall take steps to avoid taking possession of information relating to specific offences or alleged offences that have not been fully dealt with by the courts of all relevant jurisdictions.

(2) The OHA shall ensure that information received by it is kept in a secure manner that, in particular, ensures that the information is not used in a manner that breaches a person's rights under the European Convention on Human Rights. 


\section{Publication of information}

(1) Subject to the provisions of this section, oral history material shall be publicly available.

(2) The OHA shall subject all material accepted by it to a review of its sensitivity to consider whether a contribution should be kept confidential for a specified period.

(3) The OHA may keep a contribution confidential for a specified period where-

(a) the contributor so requests; or

(b) in the absence of such a request, the OHA considers that publication would present a substantive risk to an individual.

(4) Where a contributor makes a request under subsection (2), the OHA shall discuss with the contributor the appropriateness of the period requested.

(5) After such discussion, the OHA shall-

(a) comply with that request;

(b) agree with the contributor a different period; or

(c) where the OHA considers that publication would present a substantive risk to an individual, decide that the contribution shall be kept confidential for a longer period than the contributor specified.

(6) Where the OHA proposes to take any decision under subsection (2)(b) or subsection (4)(c), it must-

(a) consult the contributor on its proposal and explain its reasoning;

(b) take account of the wishes of the contributor;

(c) ensure that such a decision is taken by or on the advice of properly trained staff; and

(d) comply with international best practice.

(7) A contribution may be kept confidential for a period longer than 30 years only if the $\mathrm{OHA}$ is satisfied that publication of the contribution or the relevant part would continue to present a substantive risk to an individual.

(8) The Data Protection Acts and the Freedom of Information Act 2000 shall not apply to-

(a) oral history material provided to the OHA or any of its servants or agents during the process of a contributor making a contribution and before that contribution is finalised by the OHA; and

(b) any contribution which the OHA keeps confidential in accordance with this section.

(9) If a court orders the OHA to disclose or provide access to a contribution, the OHA shall immediately notify the relevant contributor (or next of kin) and provide them with an opportunity to make representations to the relevant authority.

(10) For the purposes of this section-

(a) a "contribution" means a contribution of oral history material made by a contributor to the OHA and may include any part thereof;

(b) a "substantive risk to an individual" means, in relation to publication of a contribution, that publication is likely to cause substantial damage or distress to a living individual or might put an individual's life at risk.

\section{Arrangements with the Republic of Ireland}

\section{Arrangements with the Republic of Ireland}

(1) For the purpose of ensuring that the OHA provides a central place for people from all backgrounds throughout the United Kingdom and Ireland to share experiences and narratives related to the Troubles, the OHA may make such arrangements with bodies in the Republic of Ireland as it sees fit. 
(2) The Northern Ireland Executive and the Secretary of State, as appropriate, shall facilitate this process, if necessary by the conclusion of arrangements between the two Governments.

\section{PART 6}

\section{GENERAL}

\section{Interpretation}

(1) In this Act-

"Coroner" means a coroner appointed under the Coroners Act (Northern Ireland) 1959;

"the founding principles" has the meaning given by section 1;

"the Historical Enquiries Team" means the Historical Enquiries Team established in September 2005 by the Police Service of Northern Ireland;

"the HIU" has the meaning given by section 5 ;

"information" includes documents, information held or recorded in any form and oral testimony provided to the ICIR;

"investigating bodies" has the meaning given by section 4;

"perpetrator" has the meaning given by section 3;

"public authority" has the same meaning as in section 6 of the Human Rights Act 1998 (acts of public authorities);

"troubles-related death" has the meaning given by section 2(1);

"troubles-related human rights breach" has the meaning given by section 2(2).

(2) References in this Act to Ministers and Departments are to Northern Ireland Ministers and Departments (except where the contrary is stated).

\section{Regulations and orders}

(1) Regulations under this Act shall be made by statutory instrument.

(2) Regulations may not be made under section [] unless a draft has been laid before and approved by resolution of each House of Parliament.*

(3) Regulations under sections 9(2), 21(1), 32(6), 33(1), 35(1), 35(2), 35(4), (35(5) and 55 shall be subject to annulment in pursuance of a resolution of either House of Parliament.

(4) Regulations may-

(a) make provision that applies generally or only in specified cases or circumstances;

(b) make different provision for different cases or circumstances;

(c) include incidental, consequential and transitional provision.

(5) An order under section 13(5) is to be treated for all procedural purposes as if it were an order under section 56(2) of the Police (Northern Ireland) Act 1998.

* This section is left open to allow the balance between negative and affirmative resolution to be determined during enactment discussions. 


\section{SCHEDULES}

SCHEDULE 1

\section{STAFF AND PROCEEDINGS OF THE DIRECTOR OF THE HISTORICAL INVESTIGATIONS UNIT}

This detailed schedule is not included in the Model Bill. The schedule would contain the details of information such as arrangements for staff pensions and conditions, applicability of a Code of Ethics and other matters.

\section{SCHEDULE 2}

\section{TEXT OF THE AGREEMENT BETWEEN THE UNITED KINGDOM AND IRELAND ON THE ESTABLISHMENT OF THE INDEPENDENT COMMISSION ON INFORMATION RETRIEVAL}

The British and Irish Governments:

Welcoming the provisions on The Past in the Stormont House Agreement reached on 23 December 2014 by themselves and the parties to the Northern Ireland Executive;

Reaffirming their commitment to the long-term peace and stability of Northern Ireland;

Remembering the victims and survivors of violence and the suffering of the families of those victims;

Recognising that the proposed Independent Commission on Information Retrieval will create the possibility for people to come forward with information that is not available from other sources;

HAVE AGREED as follows:

\section{The Commission}

\section{Establishment}

The States Parties to this Agreement agree that there shall be a Commission to be known as the Independent Commission on Information Retrieval, established in accordance with the provisions set out in this Agreement.

\section{Objective and functions}

\section{Objective}

The objective of the Commission shall be to enable victims and survivors to seek and privately receive information about troubles-related deaths of members of their families.

\section{Guiding principles}

In exercising its functions the Commission must aim to apply the guiding and additional principles set out in paragraphs 21 and 50 of the Stormont House Agreement.

\section{Specific functions}

For the purpose of achieving its objectives in accordance with the guiding principles, the Commission must-

(a) prepare, in consultation with relevant stakeholders, a non-statutory Code of Practice to provide guidance on the exercise of its functions in accordance with applicable international human rights standards;

(b) undertake outreach and other activities designed to publicise the work of the Commission and give individuals and organisations the necessary confidence to approach the Commission to provide information or to receive it;

(c) conduct research for the purpose of eliciting information or checking information received; 
(d) work with victims and survivors, and organisations representing their interests, to provide appropriate support for those who engage with the Commission, including the regular provision of information about progress;

(e) make arrangements to take statements from individuals or organisations volunteering the provision of information;

(f) make arrangements for collating and analysing information received;

(g) compile reports for victims and survivors (which may provide evidence of institutional or organisational, but not individual, responsibility for deaths);

(h) recommend thematic lines of investigation to be commissioned by the IRG;

(i) compile and retain information in a secure and confidential form during the work of the ICIR and ensure the archives are maintained inviolably and confidentially for 50 years following the completion of its work, in a form that prevents information gathered by the ICIR being disclosed to law enforcement, intelligence agencies or other persons during this period.

(j) make reports to the IRG about progress of the Commission (which may identify classes of person who have or have not cooperated with the Commission).

\section{The Commissioners}

\section{Appointment}

(1) The Commission shall consist of five Commissioners.

(2) The Chair shall be appointed by joint decision of-

(a) Her Majesty's Government in the United Kingdom, having consulted the Office of the First Minister and Deputy First Minister in Northern Ireland, and

(b) the Government of Ireland.

(3) Two Commissioners shall be appointed by joint decision of the persons mentioned in sub-paragraph (2), on the nomination of the First Minister and Deputy First Minister in Northern Ireland.

(4) The persons mentioned in sub-paragraph (2) must publish a statement of their reasons for thinking that the person appointed satisfies sub-paragraph (8), and with respect to the Chair, sub-paragraph (7).

(5) One Commissioner shall be appointed by Her Majesty's Government in the United Kingdom.

(6) One Commissioner shall be appointed by the Government of Ireland.

(7) The Chairperson must be a person of international standing and reputation.

(8) Each Commissioner must-

(a) have qualities and experience which are likely to command the respect and confidence of all participants in the functions of the Commission, including victims and survivors, governments, security services and former members of paramilitary organisations;

(b) be independent, and perceived to be independent, of all persons likely to be subject to information retrieval procedures;

(c) be impartial, and perceived to be impartial;

(d) have experience and skills which make the Commissioner suitable to handle sensitive information and to make judgements about its reliability;

(e) neither have nor expect to have any financial or other interests that are reasonably likely to conflict with the exercise of their functions as Commissioner. 
(9) The persons responsible for making appointments and nominations shall work together (in accordance with their respective domestic laws) with the aim of ensuring that the membership of the Commission includes at least two women.

\section{Tenure}

(1) The appointment of a Commissioner continues for the duration of the Commission, subject to the following provisions.

(2) Where a Commissioner resigns by notice in writing to the person who appointed or nominated the Commissioner in accordance with paragraph 4, that person may appoint or nominate a replacement.

(3) If Her Majesty's Government in the United Kingdom and the Government of Ireland, are satisfied that a Commissioner is no longer able, willing or fit to perform the functions of the office, they may dismiss the Commissioner (and a replacement shall be appointed in the same manner as the original appointment).

(4) For the purposes of sub-paragraph (3) -

(a) a person is no longer able or fit to perform the functions of the office of Commissioner if the person no longer satisfies the criteria for appointment set out in paragraph 5(8); and

(b) before taking action Her Majesty's Government in the United Kingdom must consult the Office of the First Minister and Deputy First Minister in Northern Ireland.

\section{Remuneration and allowances}

(1) Commissioners must be available to work for the Commission on a full-time basis.

(2) The Commissioners shall be paid remuneration and allowances in accordance with provision to be specified in legislation of the United Kingdom and in legislation of Ireland.

\section{Administration}

\section{Secretariat}

(1) There shall be a Secretariat to provide research and other professional and administrative support to the Commissioners.

(2) The Commissioners shall appoint the Chief Executive and other staff of the secretariat.

(3) In appointing staff the Commissioners shall aim to ensure that-

(a) the Secretariat has experience and knowledge of psychosocial and trauma counselling (including gender sensitivity),

(b) the Secretariat has experience of handling sensitive information and making judgments about its reliability, and

(c) that each member of the Secretariat satisfies the principles set out in paragraph 5(8) above.

(d) Staff may be (but need not be) appointed on secondment from a public authority.

(e) The expenses of the Secretariat shall be paid in accordance with provision to be specified in legislation of the United Kingdom and in legislation of Ireland.

\section{Funding}

(1) The States Parties to this Agreement undertake to provide the Commission with the resources reasonably necessary to perform its functions.

(2) The accounting procedures of the Commission shall be transparent, and designed to promote confidence in its independence, impartiality and integrity. 


\section{Operational}

\section{Independence}

(1) The Commission shall have full independence (including complete operational autonomy).

(2) Immunities and privileges shall be conferred on the Commission, the Commissioners and the Secretariat by legislation of the United Kingdom and legislation of Ireland.

(3) The Commission may-

(a) undertake investigations into matters whether or not they are being or have been investigated by the HIU or other public bodies, and

(b) may require the provision of information by the HIU or other public bodies for the purpose of assessing the reliability of information provided to the Commission.

(4) The Commission (subject to provisions below about confidentiality) shall at intervals of not less than a year make, and publish, a report to the Implementation and Reconciliation Group-

(a) suggesting themes for analysis, and

(b) describing the progress of the work of the Commission.

\section{Commencing an information retrieval process}

(1) The ICIR may commence an information retrieval process in response to-

(a) requests from victims and survivors that a process be opened, or

(b) requests from persons with information that a process be opened.

(2) Information retrieval processes can be opened regardless of whether they relate to a case that has previously been investigated or is in the process of being investigated by-

(a) the Police Service of Northern Ireland;

(b) the Police Ombudsman for Northern Ireland;

(c) the Royal Military Police;

(d) the Royal Ulster Constabulary;

(e) the Independent Police Complaints Commission; and

(f) the HIU.

\section{Engagement with victims and survivors}

(1) In engaging with victims and survivors the Commission shall take all reasonable steps to ensure that victims and survivors understand that their engagement is voluntary and that they may withdraw from the process at any time.

(2) The Commission shall take all reasonable steps to ensure that victims and survivors appreciate in advance potential legal consequences of engagement with the Commission.

(3) The Commission shall provide victims and survivors and other persons who engage with the Commission with such kinds of support as the Commission thinks reasonably necessary or helpful-

(a) during the information recovery process, and

(b) in dealing with the consequences of that process.

\section{Reports to victims and survivors}

(1) The Commission shall comply with any request from victims and survivors for the making of a written report in relation to a troubles-related death addressed by the Commission, detailing the steps taken in the information recovery process, including- 
(a) steps taken to test the reliability of information received, and

(b) new information that has been revealed in respect of the case.

(2) Reports given by the Commission to victims and survivors are not to be publicised by the Commission.

(3) The Commission need not comply with a request under sub-paragraph (1) unless satisfied that the information recovery process on the case concerned has reached its conclusion; but this sub-paragraph does not prevent the Commission from issuing interim reports.

(4) A report must not identify individuals who have provided information to the Commission in confidence; and the Commission shall take all necessary steps to avoid identifying persons who have provided information.

(5) A report may identify organisations that appear to be responsible for acts or omissions discussed in the report.

(6) In preparing a report the Commission must take all necessary steps to ensure that the provision of the report to victims and survivors does not infringe any person's rights under Article 2 of the European Convention on Human Rights.

(7) Persons providing information to the Commission shall benefit from privileges and immunities provided by legislation of the United Kingdom and legislation of Ireland.

\section{Expenses}

(1) The Commission may defray expenses incurred by victims and survivors or other persons communicating or otherwise cooperating with the Commission.

(2) The Commission may provide other support as it thinks fit.

\section{Obtaining information}

(1) Legislation of the United Kingdom and legislation of Ireland shall ensure that the Commission has the power to require the production from public authorities of any information that it requires in the exercise of its functions.

(2) The Commission may enter into agreements with public authorities in respect of the provision of information.

(3) The Commission may request the provision of information from public authorities outside the United Kingdom and Ireland (and Her Majesty's Government in the United Kingdom and the Government of Ireland shall support and facilitate any request).

(4) The Commission shall not take possession of articles used to commit offences.

\section{Holding and disclosing information}

(1) The Commission shall ensure that information received by it is kept in a secure manner that, in particular, ensures that the information is not used in a manner that breaches a person's rights under the European Convention on Human Rights.

(2) The Commission shall not disclose to law enforcement agencies or other public authorities-

(a) information received by it, or

(b) information that might lead to the identification of persons who provided information to it.

\section{Use of information}

(1) Legislation of the United Kingdom and legislation of Ireland shall ensure that information provided to the Commission is not admissible in criminal or civil proceedings.

(2) Sub-paragraph (1) is without prejudice to- 
(a) any use by a public authority of information in its possession which it provides to the Commission, or

(b) the prosecution of a person in reliance on evidence obtained otherwise than as a result of the provision of information to the Commission.

(3) The Commission shall ensure that a person providing information does not become liable to administrative sanctions, by reason only of providing the information.

\section{Offences}

Legislation of the United Kingdom and legislation of Ireland shall provide criminal penalties for-

(a) the provision of false information to the Commission by a person who knows the information to be false;

(b) otherwise obstructing the work of the Commission (including the destruction by a public authority of information likely to be required by the Commission);

(c) the unlawful disclosure of information by members or staff, or former members or staff, of the Commission (including after the Commission has ceased to exist).

\section{Entry into Force}

(1) The States Parties shall notify, in writing and through diplomatic channels, the completion of the legal formalities required for the entry into force of this Agreement.

(2) The Agreement will come into force on the first day of the second month after receipt of the last notification.

\section{Duration of the Agreement}

(1) This Agreement shall continue in force until terminated by mutual agreement of the two Governments.

(2) After termination this Agreement shall continue to have effect in so far as necessary for meeting liabilities of the Commission or disposing of remaining assets of the Commission, as provided for in the agreement of termination. 